\title{
Changes in insulin-like growth factor-binding protein-2 and -3 in follicular fluid during atresia of follicles grown after ovulation in pigs
}

\author{
H. D. Guthrie ${ }^{1}$, R. W. Grimes ${ }^{2}$ and J. M. Hammond ${ }^{2}$ \\ ${ }^{1}$ Agricultural Research Service, Germplasm and Gamete Physiology Laboratory, US Department of \\ Agriculture, Beltsville, MD 20705, USA; and 'Department of Medicine, Division of Endocrinology, \\ Diabetes and Metabolism, The Milton S. Hershey Medical Center, Pennsylvania State University, \\ PO Box 850, Hershey, PA 17033, USA
}

\begin{abstract}
In pigs, medium-sized follicles (3-6 $\mathrm{mm}$ in diameter), lost during preovulatory maturation, are rapidly replenished after ovulation, increasing tenfold in number between day 3 and day 8 of the oestrous cycle. The incidence of atresia in medium-sized follicles was previously found to increase between day 5 and day 7 after the onset of oestrus (day 0 ). This study was conducted to determine whether changes in concentrations of insulin-like growth factor binding proteins (IGFBPs) in pig follicular fluid from medium-sized follicles were related to increased incidence of atresia. Individual follicles were isolated on days 5, 6 and 7 after oestrus from eleven pigs. Follicles were defined as atretic when they contained $\geq 10 \%$ apoptotic granulosa cells (cells containing subdiploid amounts of DNA fluorescence determined by flow cytometry). Concentrations of IGFBP-2 and -3 were determined by ligand blot analysis with ${ }^{125}$ I-labelled insulin-like growth factor II and quantified by densitometry. The mean percentage of apoptotic cells per follicle increased ( $P \leq 0.01)$ from 3.6 to 35.0 and the mean concentration of IGFBP-2 increased $(P \leq 0.001) 3.3$-fold between day 5 and day 7 after oestrus. The concentration of IGFBP-3 did not differ significantly among days. Mean oestradiol concentration in follicular fluid decreased $(P \leq 0.05)$ from 52.3 to $0.9 \mathrm{ng} \mathrm{ml}^{-1}$ between day 5 and day 7 . Androstenedione concentrations in follicular fluid also decreased ( $P \leq 0.01$ ) between day 5 and day 7 , but progesterone did not differ significantly among days. The concentration of IGFBP-2 correlated positively with the percentage of apoptotic cells $(r=0.898, P \leq 0.001)$. The concentration of IGFBP-2 did not correlate significantly with the concentration of follicular fluid steroids or of IGFBP-3. The concentration of IGFBP-2 was three times higher in atretic than in healthy follicles $(P \leq 0.001)$, but the concentration of IGFBP-3 did not differ significantly between atretic and healthy follicles. We conclude that increased production or accumulation of IGFBP-2 could play a role in the development of apoptosis among granulosa cells and increased follicular atresia between day 5 and day 7 after oestrus. In contrast, no physiological role for IGFBP-3 in apoptosis or atresia was indicated.
\end{abstract}

\section{Introduction}

An increasing body of evidence supports a regulatory role for insulin-like growth factor I (IGF-I) and IGF-binding proteins (IGFBPs) in follicular growth and development (Adashi et al., 1989; Hammond et al., 1993). IGF-I is produced in cultured pig granulosa cells and its synthesis is stimulated by factors such as FSH, growth hormone and oestradiol. IGF-I augments FSHmediated steroidogenesis in porcine granulosa cells in vitro (Hammond et al., 1993) and synergizes with epidermal growth factor to increase DNA synthesis and cell replication (May et al., 1988). Changes in concentration of IGF-I and expression of mRNA encoding IGF-I in the follicular fluid during the

Received I February 1995 follicular phase of pigs indicate that IGF-I may be involved in or linked to the process of selection and growth of ovulatory follicles (Hammond et al., 1993).

IGFBPs, present in ovarian follicular fluid (Mondschein et al., 1991) and synthesized by cultured granulosa cells (Mondschein et al., 1990), are important in follicle development because they have the potential to antagonize the action of IGF-I and determine whether a follicle becomes preovulatory or atretic during the follicular phase of the oestrous cycle. Factors regulating atresia at the ovary are unknown, but IGFBP-2 and IGFBP-3, the most abundant IGFBPs in pig follicular fluid (Mondschein et al., 1991; Howard and Ford, 1992), are natural candidates for attenuating IGF-mediated cell proliferation (Adashi et al., 1989; Hammond et al., 1993) or survival (Collins et al., 1994). These IGFBPs were used to demonstrate inhibitory 
effects on follicular development (Bicsak et al., 1991; Chun et al., 1994) and granulosa cell function (Ui et al., 1989; Bicsak et al., 1990; Adashi et al., 1990a; Monget et al., 1993) in vitro.

Most studies of the role of the IGF system in pigs have dealt with questions concerning preovulatory follicular maturation. In contrast, very little is known about the functions of ovarian IGFs and IGFBPs in the development of follicles during other stages of the oestrous cycle. Medium-sized follicles $(3-6 \mathrm{~mm}$ in diameter) are not found during growth and maturation of ovulatory follicles (Foxcroft and Hunter, 1985) and their growth remains depressed until after ovulation (Guthrie et al., 1995). After ovulation, follicular growth resumes and the number of medium-sized follicles increases by ten times between day 3 and day 8 of the oestrous cycle (day $0=$ first day of oestrus) (Clark et al., 1975). Changes in the distribution of follicles of different sizes and total mass of follicular fluid indicate that a second group of follicles may start growing after day 8 (Clark $e t$ al., 1975). On the basis of the hypothesis that follicles in the first wave of growth after ovulation undergo atresia, follicles recovered on days 5, 6 and 7 after the onset of oestrus were examined and it was found that the incidence of atresia in medium-sized porcine follicles did increase between day 5 and day 7 (Guthrie et al., 1995). Since IGF-I synergizes with gonadotrophins to stimulate several aspects of follicle maturation and IGFBPs appear to antagonize these actions (Hammond et al., 1993), increased expression of IGFBPs may be involved in atresia. The present study was conducted to determine whether changes in IGFBPs in follicular fluid were related to an increased incidence of atresia and were affected by day of the cycle, degree of granulosa cell apoptosis, and concentrations of ovarian steroids during the first wave of follicular growth after ovulation.

\section{Materials and Methods}

\section{Animals}

Follicles were recovered on days 5,6 and 7 after the onset of oestrus (day $0=$ first day of oestrus) from four, four and three cyclic gilts, respectively. These pigs were bred for another study and were killed by electrical shock and exsanguination as described by Guthrie et al. (1995). All pigs had ovulated and had fertilized embryos. The animals used in this study were treated in accordance with the NIH Guide for the Care and Use of Experimental Animals. Experimental protocols were approved by the Beltsville Area Animal Care and Use Committee.

\section{Analysis of follicular fluid}

Follicles (3-6 $\mathrm{mm}$ in diameter) were dissected from ovaries and processed as described below. Of these follicles, 27 were randomly selected for the present study. Follicular fluid was aspirated and frozen at $-20^{\circ} \mathrm{C}$ until oestradiol, androstenedione and progesterone contents were quantified without extraction using double-antibody $\left[{ }^{125} \mathrm{I}\right]$ ligand radioimmunoassay kits (Pantex, Santa Monica, CA) (Guthrie et al., 1994). The minimum detectable amounts of oestradiol, progesterone and androstenedione were 1, 6 and 6 pg per tube, respectively.
The mean coefficient of variation (CV) of samples duplicated within assays was 11, 6 and $4 \%$ for oestradiol, progesterone and androstenedione, respectively. The $\mathrm{CV}$ of a sample repeated in each assay was 10, 12 and 10\% for oestradiol, progesterone and androstenedione, respectively.

Content of IGFBPs in follicular fluid was determined by ligand blotting as described by Mondschein et al. (1991). Briefly, $2 \mu \mathrm{l}$ of follicular fluid was subjected to electrophoresis on 15-well, precasf $12 \%$ SDS-polyacrylamide minigels (Novex, Encinitas, CA) under non-reducing conditions. Proteins were electroblotted onto nitrocellulose. IGFBPs were detected with ${ }^{125}$ I-labelled IGF-II on X-ray film and quantified by densitometry. In representative samples, the migration pattern of the specific IGFBPs was verified by immunoprecipitation (Mondschein ef al., 1990) or immunoblotting (Grimes et al., 1994a).

\section{Determination of follicular health or atresia}

After collection of follicular fluid, follicles were bisected. Granulosa cells were scraped off the follicle wall and processed separately for each follicle. Granulosa cells were fixed in $70 \%$ $(\mathrm{v} / \mathrm{v})$ ethanol and incubated overnight in a solution of propidium iodide and RNase to label DNA as described by Guthrie et al. (1994). Granulosa cells undergoing apoptosis were identified by the presence of subdiploid amounts of DNA fluorescence in cells illuminated by the $488 \mathrm{~nm}$ line of an argon laser in a Coulter Epics Profile II flow cytometer (Guthrie et al., 1994). Follicles with $<10 \%$ apoptotic $\left(A_{0}\right)$ granulosa cells were designated biochemically healthy, while those with $\geq 10 \% A_{0}$ granulosa cells were designated biochemically atretic according to criteria established by Guthrie et al. (1994, 1995).

\section{Statistical analyses}

Data regression and analysis of variance were performed on data from the 27 follicles (SAS, 1987). Owing to the increased proportion of atretic follicles between day 5 ( 1 of 10) and day 7 (6 of 9), effects of day and follicle health class (atretic or healthy) were analysed separately. Comparisons among day means were by Duncan's multiple-range test.

\section{Results}

The relationships between day of the cycle, follicular health class, and steroid concentrations in follicular fluid were previously examined for the full set of 113 follicles (Guthrie et al., 1995). The present study of 27 randomly selected follicles examined the relationship between these parameters and concentrations of IGFBP-2 and -3 in follicular fluid. Previously the incidence of atretic follicles (those with $\geq 10 \% A_{0}$ cells) per gilt increased from $6 \%$ on day 5 to $50 \%$ on day 7 (Guthrie et al., 1995). The number of atretic follicles used in the study reported here reflected these proportions with 1 of 10,3 of 8 , and 6 of 9 follicles classified as atretic on days 5,6 , and 7 , respectively.

The percentage of $A_{0}$ cells per follicle was used as an indicator of atresia. The percentage of $A_{0}$ cells increased $(P \leq 0.01)$ (Fig. 1a) and the mean concentration of oestradiol in 

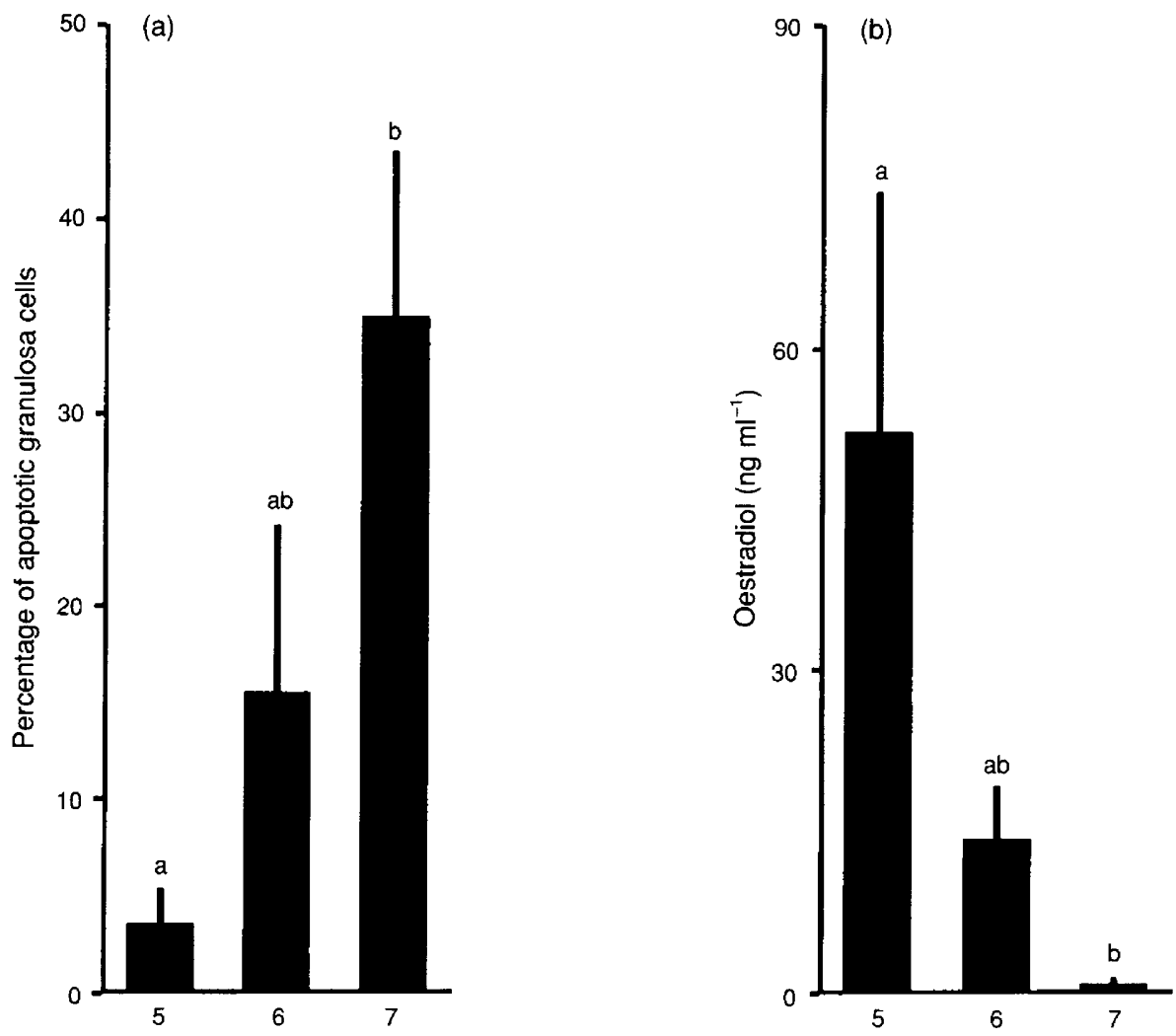

Day of oestrus

Fig. 1. Changes in (a) percentage of apoptotic granulosa cells and (b) concentration of oestradiol in follicular fluid during the early luteal phase in pigs. Values are means \pm SEM. ${ }^{\text {ab }}$ Significantly different $(P \leq 0.05)$.

Table 1. Linear correlations among follicular variables in pigs during the early luteal phase $(n=27)$

\begin{tabular}{lcc}
\hline Variable & IGFBP-2 & IGFBP-3 \\
\hline Follicle diameter & 0.063 & $0.397^{*}$ \\
$\% A_{\circ}$ cells & $0.898^{* *}$ & -0.186 \\
Oestradiol & -0.333 & -0.044 \\
Androstenedione & -0.336 & -0.207 \\
Progesterone & 0.177 & -0.257 \\
IGFBP-3 & 0.052 & \\
\hline
\end{tabular}

IGFBP: insulin-like growth factor binding protein. Significantly different $\left({ }^{*} P<0.05 ; * * P<0.001\right)$.

$\% A_{0}$ : percentage of apoptotic granulosa cells.

follicular fluid decreased $(P \leq 0.05)$ between day 5 and day 7 (Fig. Ib). Among individual follicles, the linear correlation between percentage of $A_{0}$ cells and oestradiol concentration was negative, but not significant (Table 1 ). The mean concentration of IGFBP-2 increased $(P \leq 0.01)$ 3.3-fold between day 5 and day 7 after oestrus (Fig. 2a), while the concentration of IGFBP-3 did not differ significantly among days (Fig. 2b). The concentration of androstenedione in follicular fluid (mean \pm SEM) decreased $(P \leq 0.01$ ) between day 5 and day 7 with values of $81.9 \pm 27.8,36.1 \pm 7.5$, and $12.6 \pm 2.3 \mathrm{ng} \mathrm{ml}^{-1}$, respectively, on days 5,6, and 7 (data not shown). The concentration of progesterone in follicular fluid did not differ significantly among days (data not shown). Concentrations of IGFBP-2 and -3 were also compared with the degree of atresia as measured by the percentage of $A_{0}$ cells. A ligand blot of porcine follicular fluid IGFBPs accompanied by the percentage of $A_{0}$ cells for 12 follicles (Fig. 3) shows that the amount of IGFBP-2, but not of IGFBP-3, increased as follicles became more atretic, containing a greater percentage of apoptotic granulosa cells. The ligand blot also showed that the amounts of IGFBPs of lower molecular weight than IGFBP-2, such as IGFBP-4 and -5 , were very low compared with the amounts of IGFBP-2 and -3 in this study. The concentration of IGFBP-2 correlated positively with the percentage of $A_{0}$ cells per follicle (Fig. $4 ; r=0.898, P \leq 0.001$ ). The positive correlation between IGFBP-2 concentration and the percentage of $A_{0}$ cells was independent of their joint correlation with day (partial correlation with effect of day removed, $r=0.847, P \leq 0.001$ ). The concentration of IGFBP-2 was not significantly correlated with the concentrations of follicular fluid steroids or of IGFBP-3 (Table 1). The concentration of IGFBP-3 correlated with follicle size, but not with any other follicular variable (Table 1). When follicles were grouped according to biochemical health class, the concentration of IGFBP- 2 in atretic follicles was three times greater $(P \leq 0.001)$ than that in healthy follicles. In contrast, IGFBP-3 concentration did not differ significantly between atretic and healthy follicles (data not shown). 

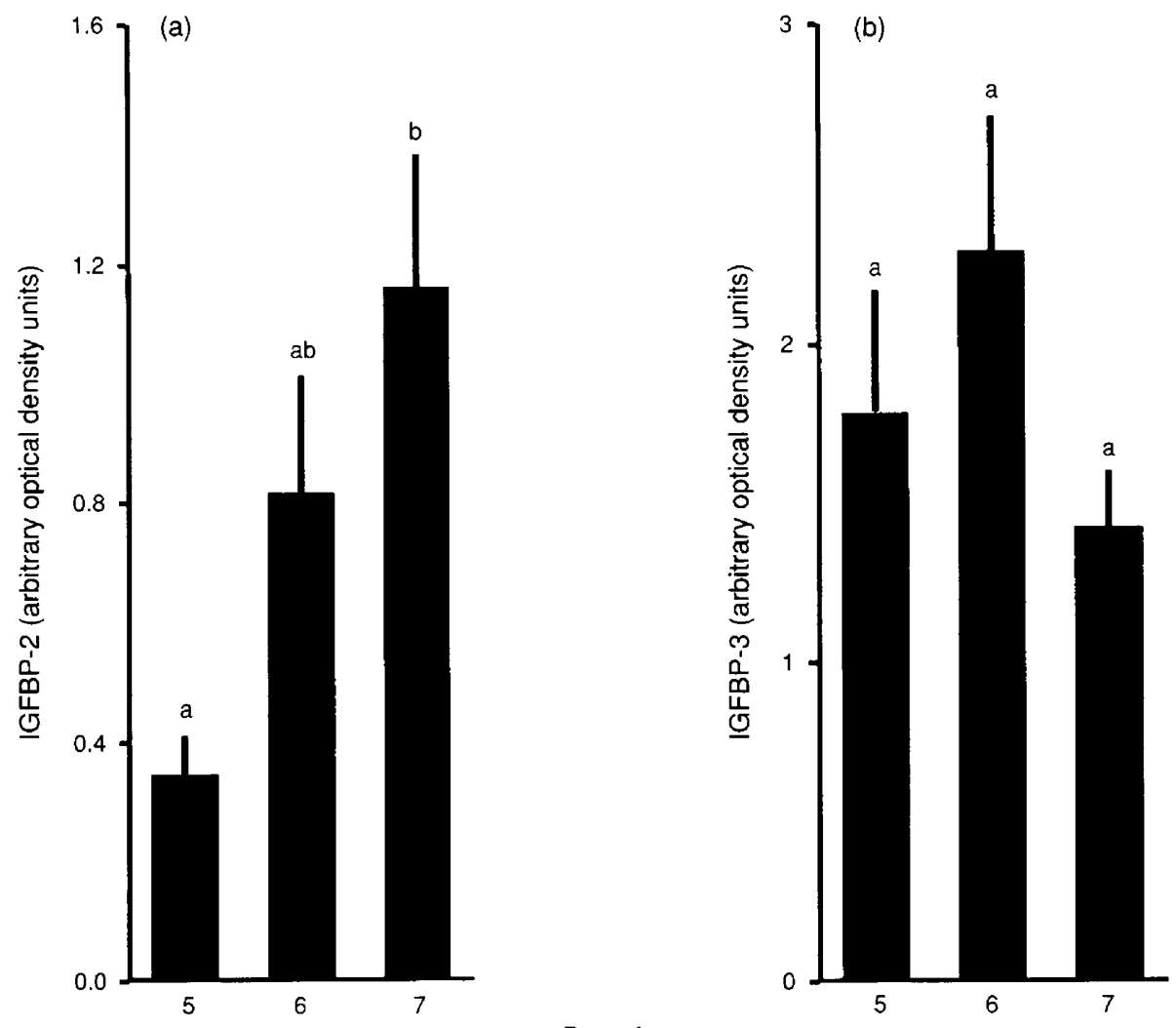

Fig. 2. Changes in concentrations (arbitrary optical density units) of (a) insulin-like growth factor binding protein-2 (IGFBP-2) and (b) IGFBP-3 in porcine follicular fluid during the early luteal phase. Values are means \pm SFM. ${ }^{\text {ab }}$ Significantly different $(P \leq 0.05)$.

\section{Discussion}

The results of the present study provide evidence for the involvement of the ovarian IGF system in atresia among the first group of follicles grown after ovulation in pigs. The replenishment of the population of medium-sized follicles, depleted during the growth of the ovulatory follicles, begins soon after ovulation in pigs (Guthrie et al., 1995). However, by day 7 after oestrus, most medium-sized follicles appear to undergo atresia as indicated by a high incidence of granulosa cell DNA fragmentation (apoptosis), morphology of freshly isolated granulosa cells, and low oestradiol production in vivo (Guthrie et al., 1995).

In the present study, the higher concentration of IGFBP-2 in fluid from atretic follicles compared with healthy follicles, indicates a physiological regulation of IGFBP-2 synthesis during atresia. The concentration of IGFBP-2 correlated positively with the percentage of $A_{0}$ granulosa cells in the present study and in our previous study of follicular atresia during preovulatory follicle maturation in pigs (Grimes et al., 1994b). This strong correlation indicates that apoptotic cell death of granulosa cells is a function of changes in the relative amounts of IGFs and IGFBP-2. The concentration of IGFBP-2 was also found to be increased in the fluid of atretic follicles of ewes (Monget et al., 1993), women (Cataldo and Giudice, 1992; San Roman and Magoffin, 1993) and cows (Echternkamp et al., 1994), suggesting a role for IGFBP-2 in atresia in these four species. Previously, in pigs, physiological regulation of IGFBP-2 was indicated because both follicular fluid IGFBP-2 (Mondschein et al., 1991; Howard and Ford, 1992), and mRNA encoding IGFBP-2 in the follicle wall (Samaras et al, 1993) decreased during preovulatory follicle maturation. However, in these studies atretic and healthy follicles were not analysed separately. Thus, the higher amount of IGFBP- 2 expression in small follicles compared with large, preovulatory follicles may indicate that a greater proportion of the small follicles were atretic (Guthrie et al., 1993, 1994).

In contrast to IGFBP-2, no evidence of a physiological role for IGFBP-3 in follicular atresia was found in the present study or in our previous study of follicular atresia during preovulatory follicle maturation (Grimes et al,, 1994b). IGFBP-3 was abundant in pig follicular fluid, but did not correlate significantly with the percentage of $A_{0}$ granulosa cells nor was the concentration of IGFBP-3 higher in atretic compared with healthy follicles. IGFBP-3 was not correlated with follicular atresia in women (Cataldo and Giudice, 1992; San Roman and Magoffin, 1993), ewes (Monget et al., 1993), or cows (Echternkamp et al., 1994). Results of our earlier studies indicate that production of IGFBP-3 by porcine follicles in vivo may be very low because mRNA encoding IGFBP-3 could not be detected by northern blot analysis in granulosa cells and was expressed at very low concentrations in theca interna tissue (Samaras et al., 1992). High concentrations of IGFBP-3 in follicular fluid could originate in theca interna, adjacent vascular 


\begin{tabular}{|l|c|c|c|c|c|c|c|c|c|c|c|c|}
\hline Sample & 1 & 3 & 3 & 4 & 5 & 6 & 7 & 8 & 9 & 10 & 11 & 12 \\
\hline$\% A_{0}$ cells & 26 & 20 & 2 & 0.9 & 30 & 50 & 63 & 55 & 64 & 1 & 7 & 41 \\
\hline
\end{tabular}

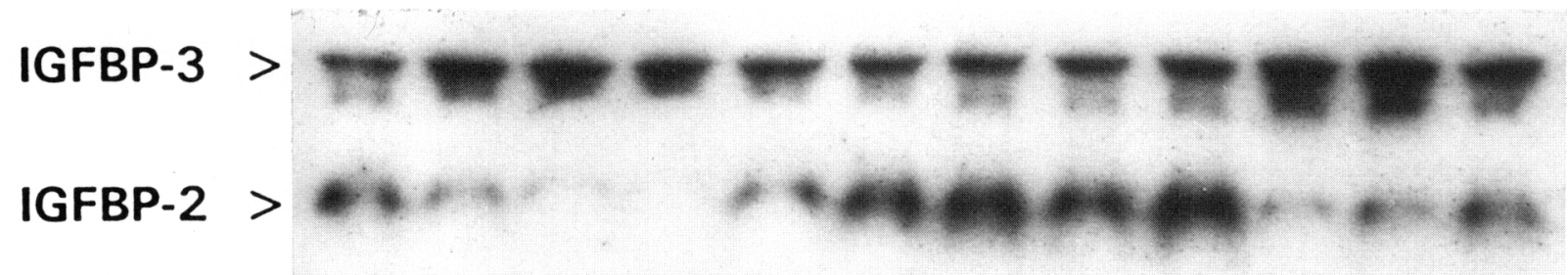

IGFBP-5 >

IGFBP-4 >

Fig. 3. Ligand blot of ${ }^{125}$ I-labelled insulin-like growth factor-II (IGF-II) binding to IGF-binding proteins (IGFBPs) in 12 pig follicular fluid samples and corresponding percentage of apoptotic $\left(\% A_{0}\right)$ granulosa cells from the same 12 follicles.

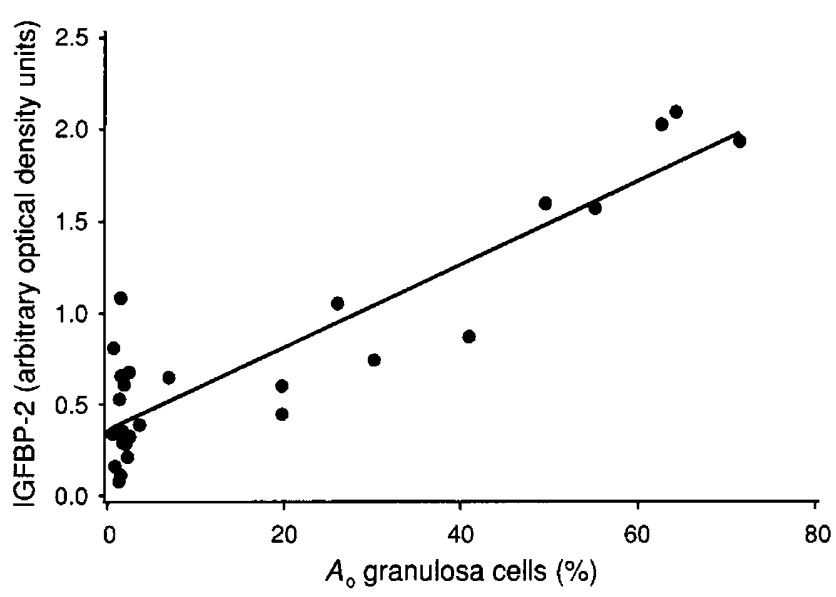

Fig. 4. Relationship between insulin-like growth factor binding protein 2 (IGFBP-2) concentrations (arbitrary optical density units) and percentage of granulosa cell apoptosis $\left(A_{0}\right)$ in follicular fluid from individual healthy and atretic pig follicles $(r=0.898 ; n=27$; $P \leq 0.001$ ).

tissue (Cohick et al., 1993; Taylor et al., 1993), or from serum (Hammond et al., 1993).

In the present study, IGFBP-4 and -5 were low to nondetectable in follicular fluid as shown by Grimes et al. (1994b), precluding meaningful comparison between atretic and healthy follicles. Therefore, IGFBP-4 and -5 may not have an important role in follicle atresia in pigs. In contrast, these peptides can be detected in small follicles, mainly atretic, from immature animals (Mondschein et al., 1991) as well as in media conditioned by immature porcine granulosa cells (Grimes et al., 1994a). These data indicate that the current methods have adequate sensitivity to detect IGFBP-4 and -5 . Atretic follicles were found to contain increased amounts of IGFBP-4 in sheep (Monget et al., 1993), humans (Cataldo and Giudice, 1992) and cows (Echternkamp et al., 1994). In rats, the amount of mRNA encoding IGFBP-4 was high in atretic compared with healthy follicles (Erickson et al., 1992). Thus both IGFBP-2 and IGFBP-4 are correlated with atresia in rats, sheep, humans and cows.

Atresia among antral follicles is considered to be a function of gonadotrophin withdrawal and local ovarian regulation (reviewed in Tsafriri and Braw, 1984). Previous studies in pigs on changes in circulating concentrations of gonadotrophins during preovulatory maturation or during FSH treatment suggest that the pattern of growth and atresia among mediumsized follicles may be related to changes in circulating concentrations of FSH (Guthrie et al., 1987, 1988, 1993). Atresia among non-ovulatory follicles, coincident with growth and maturation of the ovulatory cohort of follicles, is accompanied by decreased circulating concentrations of FSH (Guthrie et al., 1993، 1994). The growth of medium-sized follicles after ovulation may be a result of the secondary surge of FSH secretion (periovulatory FSH surge) that reaches a maximum on days 2 and 3 of the oestrous cycle (Guthrie and Bolt, 1985). Increased atresia in follicles on day 7 in the present study may be a result of a decline in circulating concentrations of FSH following the periovulatory surge of FSH (Guthrie and Bolt, 1985).

The well-established effects of FSH on the granulosa cell IGF system, stimulatory for IGF-I (Adashi et al., 1989; Hammond et al., 1993) and inhibitory for IGFBP production in vitro (Adashi et al., 1990b; Grimes et al., 1992) suggest a possible mechanism for FSH interface with the ovarian IGF system in vivo. Reduced concentrations of FSH could result in reduced IGF-I action by decreased IGF-I and increased IGFBP production. The results of the present study indicate that IGFBP-2, but not IGFBP-3, is dependent upon FSH action in vivo. We conclude that increased production or accumulation of IGFBP-2 could play a role in follicular atresia between day 5 and day 7 after oestrus. In contrast, no physiological role for IGFBP-3 in apoptosis or atresia was indicated. 
This work was supported by NIH grant ROI-HD24565. The authors thank B. S. Cooper for his technical assistance with this study. Mention of a trade name or proprietary product does not constitute a guarantee or warranty by the USDA and does not imply approval to the exclusion of others not mentioned.

\section{References}

Adashi EY, Resnick CE, Hernandez ER, Svoboda ME and Van Wyk JJ (1989) Potential relevance of insulin-like growth factor I to ovarian physiology: from basic science to clinical application Endocrine Review 7 94-99

Adashi EY, Resnick CE, Ricciarelli E, Hurwitz A, Kokia E, Tedeschi C, Botero L, Hernandez ER and Rosenfeld R (1990a) Granulosa cell-derived insulin-like growth factor (IGF) binding proteins are inhibitory to IGF-1 hormonal action. Evidence derived from the use of a truncated IGF-I analogue Molecular and Cellular Endocrinology $89 \mathrm{RI}-4$

Adashi EY, Resnick CE, Hernandez ER, Hurwitz A, Rosenfeld R, Carlsson-Skwirut C and Francis GL (1990b) Follicle-stimulating hormone inhibits the constitutive release of insulin-like growth factor binding proteins by cultured rat granulosa cells Endocrinology 126 1305-1306

Bicsak TA, Motoyuki S, Malkowski M and Ling N (1990) Insulin-like growth factor-binding protein (IGF-BP) inhibition of granulosa cell function: effect on cyclic adenosine $3^{\prime}, 5^{\prime}$-monophosphate, deoxyribonucleic acid synthesis, and comparison with the effect of an IGF-I antibody Endocrinology 126 $2184-2189$

Bicsak TA, Ling N and DePaolo LV (1991) Ovarian intrabursal administration of insulin-like growth factor-binding protein inhibits follicle rupture in gonadotropin-treated immature female rats Biology of Reproduction 44 599-603

Cataldo NA and Giudice LC (1992) Insulin-like growth factor binding protein profiles in human ovarian follicular fluid correlate with follicular functional status Journal of Clinical Endocrinology and Metabolism 74 821-829

Chun S-Y, Billig H, Tilly JL, Fututa I, Tsafriri A and Hsueh ATJ (1994) Gonadotropin suppression of apoptosis in cultured preovulatory follicles: mediatory role of endogenous insulin-like growth factor I Endocrinology 135 18451853

Clark JR, First NL, Chapman AB and Casida LE (1975) Ovarian follicular development during the estrous cycle in gilts following electrocautery of follicles Journal of Animal Science 41 1105-1111

Cohick WS, Gockerman A and Clemmons DR (1993) Vascular smooth muscle cells synthesize two forms of insulin-like growth factor binding proteins which are regulated differently by the insulin-like growth factors Journal of Cell Physiology 157 52-60

Collins MKL, Perkins GR, Rodriguez-Tarduchy G, Nieto MA and Lopez-Rivas A (1994) Growth factors as survival factors: regulation of apoptosis Bioessays 16 133-138

Echternkamp SE, Howard HJ, Roberts JG and Wise T (1994) Relationships among concentrations of steroids, insulin-like growth factor-I, and insulin-like growth factor binding proteins in ovarian follicular fluid of beef cattle Biology of Reproduction $\mathbf{5 1}$ 971-981

Erickson GF, Nakatani A, Ling N and Shimasaki S (1992) Cyclic changes in insulin-like growth factor-binding protein-4 messenger ribonucleic acid in rat ovary Endocrinology 130 625-636

Foxcroft GR and Hunter MG (1985) Basic physiology of follicular maturation in the pig journal of Reproduction and Fertility Supplement 33 1-19

Grimes RW, Samaras SE, Barber JA, Shimasaki S, Ling N and Hammond JM (1992) Gonadotropin and cAMP modulation of IGF binding protein production in ovarian granulosa cells American Journal of Physiology 262 E497-E503

Grimes RW, Barber JA, Shimasaki S, Ling N and Hammond JM (1994a) Porcine ovarian granulosa cells secrete insulin-like growth factor (IGF)-binding proteins- 4 and -5 and express their mRNAs: regulation by FSH and IGF-I Biology of Reproduction 50 695-701

Grimes RW, Guthrie HD and Hammond JM (1994b) Insulin-like growth factorbinding proteins -2 and -3 are correlated with atresia and preovulatory maturation in the porcine ovary Endocrinology 136 1996-2000
Guthrie HD and Bolt DJ (1985) Pituitary and ovarian hormone secretion and ovulation in gilts injected with gonadotropins during and after oral administration of progesterone agonist (altrenogest) Biology of Reproduction $33679 \cdots 689$

Guthrie HD, Bolt DJ, Kiracofe GH and Miller KF (1987) Effect of charcoalextracted porcine follicular fluid and $17 \beta$-estradiol on follicular growth and plasma gonadotropins in gilts fed a progesterone agonist (altrenogest) Journal of Animal Science 64 816-826

Guthrie HD, Bolt DJ, Kiracofe GH and Miller KF (1988) Ovarian response to injections of charcoal-extracted porcine follicular fluid and porcine folliclestimulating hormone in gilts fed a progesterone agonist (altrenogest) Biology of Reproduction 38 750-755

Guthrie HD, Bolt DJ and Cooper BS (1993) Changes in follicular estradiol-17 $\beta$, progesterone and inhibin immunoactivity in healthy and atretic follicles during preovulatory maturation in the pig. Domestic Animal Endocrinology 10 $127-140$

Guthrie HD, Welch GR, Cooper BS, Zakaria AD and Johnson LA (1994) Flow cytometric determination of degraded deoxyribonucleic acid in granulosa cells to identify atretic follicles during preovulatory maturation in the pig Biology of Reproduction 50 1303-1311

Guthrie HD, Cooper BS, Welch GR, Zakaria AD and Johnson LA (1995) Atresia in the first wave of follicular growth after ovulation in the pig: measurement of increased apoptosis in granulosa cells and reduced follicular fluid estradiol-17ß Biology of Reproduction 52 920-927

Hammond JM, Samaras SE, Grimes R, Leighton J, Barber J, Canning SF and Guthrie HD (1993) The role of insulin-like growth factors and epidermal growth factor-related peptides in intraovarian regulation in the pig ovary Journal of Reproduction and Fertility Supplement 48 117-125

Howard HJ and Ford JJ (1992) Relationships among concentrations of steroids, inhibin, insulin-like growth factor-I (IGF-I), and IGF-binding proteins during follicular development in weaned sows Biology of Reproduction 47 193-201

May JV, Frost JP and Schomberg DW (1988) Differential effects of epidermal growth factor, somatomedin-C/insulin-like growth factor I, and transforming growth factor-beta on porcine granulosa cell deoxyribonucleic acid synthesis and cell proliferation Endocrinology 123 I68-179

Mondschein, JS, Smith SA and Hammond JM (1990) Production of insulin-like growth factor binding proteins (IGFBPs) by porcine granulosa cells: identification of IGFBP-2 and -3 and regulation by hormones and growth factors Endocrinology 127 2298-2306

Mondschein JS, Etherton TD and Hammond JM (1991) Characterization of insulin-like growth factor binding proteins of porcine ovarian follicular fluid Biology of Reproduction 44 315-320

Monget P, Monniaux D, Pisselet C and Durand P (1993) Changes in insulin-like growth factor-I (IGF-I), IGF-II, and their binding proteins during growth and atresia of ovine ovarian follicles Endocrinology 132 1438-1446

Samaras SE, Hagen DR, Shimasaki S, Ling N and Hammond JM (1992) Expression of insulin-like growth factor-binding protein-2 and -3 messenger ribonucleic acid in the porcine ovary: localization and physiological changes Endocrinology $130 \quad 2739-2744$

Samaras SE, Guthrie HD, Barber JA and Hammond JM (1993) Expression of the $m R N A s$ for the insulin-like growth factors and their binding proteins during development of porcine ovarian follicles Endocrinology 133 2395-2398

San Roman GA and Magoffin DA (1993) Insulin-like growth factor-binding proteins in healthy and atretic follicles during natural menstrual cycles Journal of Clinical Endocrinology and Metabolism 76 625-632

SAS/STAT Guide for Personal Computers (1987) Version 6 p. 1028 SAS Institute Inc. Cary, NC

Taylor WR, Nerem RM and Alexander RW (1993) Polarized secretion of IGF-I and IGF-I binding protein activity by cultured aortic endothelial cells Journal of Cell Physiology 154 139-142

Tsafriri A and Braw RH (1984) Experimental approaches to atresia in mammals. In Oxford Reviewos of Reproduction Biology 6 226-265

Ui M, Shimonaka M, Shimasaki S and Ling N (1989) An insulin-like growth factor-binding protein blocks follicle-stimulating hormone-stimulated steroid production by ovarian granulosa cells Endocrinology 125 2184-2189 